ARNAUd FosSIER*

\title{
WHAT EXACTLY IS THE FORUM CONFESSIONIS? SECRECY AND SCANDAL IN CHURCH GOVERNANCE $\left(12^{\text {th }}-14^{\text {th }}\right.$ CENTURIES)
}

First of all, let us establish the difference between secrecy and privacy. In latin, secretum comes from secernere which means to isolate, to distinguish or to put something aside. According to this etymology, «secret» or «secrecy» refers to institutions and governance, since the verb secernere indicates the sovereign gesture of hiding something or reserving it for a small group of individuals. Does not the piece of furniture we call a «secretaire», whose drawers contain objects and papers we do not want to be visible, remind us of the gesture of hiding or concealing? In the same way, the office of «secretary» refers to the political function that consists in working in the shadow of a public authority.

Policy secrets or confidential information are not topics we will deal with here, even though they are obviously related to the growth of the modern State in the West. Among the many forms of institutional secrecy - spying, torture, judicial instruction, denounciation - I will focus here only on one, that of confession, which is at the same time specific and paradigmatic of the way Roman Church used secrecy as a tool for the judgement and government of Christians in the Middle Ages.

When we read or hear the word «confession», I assume we immediately think about sacramental confession and about the «seal of confession» (sigillum confessionis), that is to say the secrecy of the confession of sins that the Parisian master in theology Pierre le Chantre theorizes at the end of the $12^{\text {th }}$ century ${ }^{1}$. A few years later (1215), annual confession to a parish priest (proprius sacerdos) becomes a legal obligation under the canon 21 of the Fourth Lateran Council ${ }^{2}$, but we know private and secret confession

* Université de Bourgogne; arnaud.Fossier@u-bourgogne.fr. I would like to express my thanks to Armando Torres, Sara McDougall and James Plumtree for having revised this paper.

${ }^{1}$ Pierre le Chantre, Summa de sacramentis et animae consiliis, Secunda pars. Tractatus de paenitentia et excommunicatione, Ed. by J.-A. Dugauquier, Nauwelaerts, Louvain 1957; L. Honoré, Le secret de la confession, Ch. Beyaert, Bruges 1924, p. 47, n. 3; J. Chiffoleau, «"Ecclesia de occultis non iudicat" ? L'Église, le secret et l'occulte du XII au XVe siècle», Il segreto nel Medioevo. Micrologus, Nature, Sciences and Medieval Societies, 13 (2005) 359-481, particularly pp. 382-385 , quoting the texts of $12^{\text {th }}-13^{\text {th }}$ centuries which attempt to protect the secret of the confession.

${ }^{2}$ P.-M. Gy, «Le précepte de la confession annuelle et la nécessité de la confession», Revue des sciences philologiques et théologiques, 63 (1979) 529-547; J. AvRIL, «À propos du "proprius sacerdos": quelques réflexions sur les pouvoirs du prêtre de paroisse», in S. KUTTNER - K. PENNINGTON (eds.), Proceedings of the Fifth International Congress of Medieval Canon Law (Salamanca, 21-25 sept. 1976), Biblioteca Apostolica Vaticana, Vatican City 1980, pp. 471-486; N. BÉRIOU, «Autour de Latran IV (1215): la naissance de la confession moderne et sa diffusion», in Groupe de la Bussière (ed.), Pratiques de la confession, Cerf, Paris 1983, pp. 73-93. 
already existed, as monastic rules of the $5^{\text {th }}$ and $6^{\text {th }}$ centuries and Penitential Books of the $7^{\text {th }}$ and $8^{\text {th }}$ centuries can attest ${ }^{3}$. During the $12^{\text {th }}$ century then, confession clearly achieves a sacramental value in penance theories, of which many, such as those of Pierre Lombard, stress the sacerdotal power to absolve and forgive sins ${ }^{4}$. Meanwhile, confession becomes a fundamental part of civil and criminal procedures and also the core of inquisitorial procedure ${ }^{5}$.

The word confessio itself can be found everywhere when dealing with the documentation of a more «administrative» nature. In the letters and the letter formularies of the Apostolic Penitentiary - a papal office which arises at the beginning of the $13^{\text {th }}$ century, but whose activity and jurisdiction are obscure since it responds to supplications addressed to the pope, but also «receive[s] confessions» from pilgrims and penitents ${ }^{6}$ -, «confession» often defines the oral way by which a request is introduced, as it was the case in Roman procedure ${ }^{7}$. This was carried out in the presence of the Cardinal Penitentiary or of one of the members of his staff, largely composed of Friars. We easily find some examples of the word «confession» bearing this meaning in the first known letter formulary of the Apostolic Penitentiary. This formulary has been attributed to the magister and papal vice-Chancellor Thomas of Capua, but it more likely written between 1230 and 1270 .

Archiepiscopo Mediolanensi et fratri S. priori provinciali fratrum predicatorum in Lombardia. Litteras vestras, domine archiepiscope, et aliorum proborum virorum testimonium pro $\mathrm{H}$. presbitero latore presentium venerabili patri domino S. tituli sancti Marci presbitero cardinali transmissas inspeximus et ipsius presbiteri confessionem audivimus diligenter. Quia vero negotium fidei tangitur, [...] predictum [H.] de speciali mandato domini pape ad vos duximus remittendum, vestre prudentie committentes quatenus, inquisitis etc. [...]. Tenorem autem ipsarum litterarum et confessionem eiusdem vobis sub sigillo nostro remittimus ad cautelam ${ }^{8}$.

${ }^{3}$ A. Firey (ed.), A New History of Penance, E. J. Brill, Leiden-Boston 2008.

${ }^{4} \mathrm{P}$. AnciauX, La théologie du sacrement de pénitence, Nauwelaerts, Louvain 1949.

${ }^{5}$ H. J. Budischin, Der gelehrte Zivilprozess in der Praxis geistlicher Gerichte des 13. und 14. Jahrhunderts im deutschen Raum, Röhrscheid, Bonn 1974, particularly pp. 178-182; J. Chiffoleau, «Sur la pratique et la conjoncture de l'aveu judiciaire en France du XIII ${ }^{\mathrm{e}}$ au XV $\mathrm{XV}^{\mathrm{e}}$ siècle», in L'aveu. Antiquité et Moyen-Âge, Actes de la Table ronde organisée par l'École Française de Rome avec le concours du CNRS et de l'Université de Trieste (Rome, 28-30 mars 1984), École Française de Rome, Rome 1986, pp. 341-380.

${ }^{6}$ Giraldi Cambrensis Opera, J. S. Brewer (ed.), vol. 1, Londres 1861, pp. 188-189, «De invectionibus», lib. VI, c. $26 .:$ «Erat autem cardinalis, qui confessiones pro papa tunc recipiebat, responsio talis: "Iohannes de S. Paulo, titulo S. Prisce card., nobili viro Philippo de Barri salutem..."». About the origins of the Apostolic Penitentiary, see M. SodI - J. ICKx (ed.), La Penitenzieria Apostolica e il sacramento della penitenza. Percorsi storici, giuridici, teologici e prospettive pastorali, Libreria Editrice Vaticana, Vatican City 2009; A. Fossier, La fabrique du droit. Casuistique, qualifications juridiques et pratiques administratives de la Pénitencerie Apostolique, PhD (supervisor: J. ChIfFoleau), EHESS, Paris 2012, chap. 1.

${ }^{7}$ Y. Thomas, «Confessus pro iudicato. L'aveu civil et l'aveu pénal à Rome», in L'aveu. Antiquité et Moyen-Âge, op. cit., pp. 89-117.

${ }^{8}$ Thomas de Capoue, A Formulary of the papal Penitentiary in the XIII ${ }^{\text {th }}$, Ed. by H. C. LEA (ed.), Lea Brothers, Philadelphia 1892, p. 52, XXXIV, 3. 
When a supplicant applies to the pope through the penitentiaries, the sacramental nature of his confessio remains therefore uncertain. In any case, during the whole of the $13^{\text {th }}$ century, the separation between the sacramental absolution and the breaking of an excommunication is all the less explicit and the a jure or ipso facto excommunication, which proceeds from the sin itself and not from a judicial sentence, contributes to the interference between the sacramental sphere of judgment and the administrative or judicial sphere of judgment ${ }^{9}$. Moreover, we know that at the beginning of the $14^{\text {th }}$ century the pope delegated to the Friars the power to absolve sin and excommunication at the same time ${ }^{10}$. Therefore, we cannot always know if the absolutio we find in the letters formularies of the Apostolic Penitentiary consists of remitting a sin or lifting an excommunication.

In these sources, the word confessio occurs also frequently in the genitive case, related to the word forum (forum confessionis). Forum is a deeply polysemic word, which can be translated as territorial jurisdiction (either ecclesiastical or civil), according to its use in the Roman law ${ }^{11}$. However, more largely, it can also mean, at the beginning of the $13^{\text {th }}$ century, a sphere of judgment «in which a case, a power and a rule meet each other» ${ }^{12}$. The different names of the fora we find in the canonical and theological sources of the $13^{\text {th }}$ century suggest that many spheres of judgment coexisted, which were neither equivalent nor completely disconnected: forum conscientiae, forum poenitentiae, forum confessionis, forum Dei, forum spirituale, forum animae, forum exterius, forum iudiciale, forum contentiosum, forum Ecclesiae, forum exterioris Ecclesiae, forum publicum et publice, forum contentiosae iurisdictionis etc. ${ }^{13}$ The distinctions among all these for a did not refer to a practical border, since matters, procedures and sentences were often common to them ${ }^{14}$. Besides, an institution like the Penitentiary was able to choose, depending on the case, one forum or another.

The purpose of this paper is to describe what characterizes the forum confessionis, which is also called forum conscientiae or forum poenitentiae in the letter formularies of the Penitentiary, and to explain its connection with secrecy.

${ }^{9}$ E. Vernay, «Introduction», in Bérenger Frédol, Liber de excommunicatione, E. Vernay (ed.), Arthur Rousseau, Paris 1912, pp. xxxvii-xlvi; P. HuIzING, «The Earliest Development of Excommunication latae sententiae by Gratian and the Earliest Decretists», Studia Gratiana, 3 (1955) 279-320; A. LeFEBVRe-Teillard, «L'excommunication dans le droit canonique classique (XII ${ }^{\mathrm{e}}$-XIII' ${ }^{\mathrm{e}}$ siècle)», in J. Hoareau-Dodinau - P. TeXIER (eds.), La Peine. Discours, pratiques, représentations, Pulim, Limoges 2005, pp. 31-44 (Cahiers de l'Institut d'anthropologie juridique, 12).

${ }^{10}$ E. Brambilla, Alle origini del Sant'Uffizio. Penitenza, confessione e giustizia spirituale dal medioevo al XVI secolo, il Mulino, Bologna 2000, p. 121.

${ }^{11}$ B. FrIEs, Forum in der Rechtssprache, M. Hueber, Munich 1963, pp. 23-78 (Münchener theologische Studien, 17).

${ }^{12}$ P. Prodi, Christianisme et monde moderne. Cinquante ans de recherche, Seuil - Gallimard - EHESS, Paris 2006, p. 331.

${ }^{13} \mathrm{G}$. SARACENI, Riflessioni sul foro interno nel quadro generale della giurisdizione della Chiesa, CEDAM, Padoue 2002 [1961], pp. 31-32, quoting the Thomas Aquinas' Commentary on the Sentences, the Raymond of Peñafort's Summa poenitentiae and the Henry of Segusio's Summa Aurea.

${ }^{14}$ J. GoERING, «The Internal Forum and the Literature of Penance and Confession», Traditio, 59 (2004) 175-228, p. 176. 
What struck me during my dissertation research was that the forum of the confession is not only mentioned in cases of secret confession or sacramental absolution of sins, as we might expect, but also in cases of dispensation (dispensatio). Dispensation is a measure which suspends the legal rule in a single case and which generally consists in authorizing somebody to accomplish an action or get a status that the law theoretically forbids him given his situation ${ }^{15}$. It is not rare to see such dispensations granted in secret, at the forum confessionis or conscientiae.

In the letter collection composed in 1289 by the Cardinal Penitentiary Bentivenga ${ }^{16}$, we find among others examples a dispensation granted in foro conscientie which can help us understand the features of this forum. The letter is adressed to the Premonstrate abbot of Saint-Martin-de-Laon. It grants a dispensation to a monk guilty of having injured a friend with whom he used to play when he was a child, and without first obtaining absolution having then entered in a religious order and, finally, having been consecrated as a priest. So, what is at stake here is the «irregularity» of this monk (irregularitas). Since the decretists like Rufinus in the 1160s have defined it, irregularity refers to the status of somebody who has committed a fault or a crime barring him from holy orders ${ }^{17}$, but it never qualifies the sin nor the crime itself. Consequently, irregularity does not have to be confessed nor absolved by a priest; it is only a matter of administration and clerical discipline, as the final terms of our letter show:

Cum de dicto casu scandalum nullum esset, super irregularitate quam inde contracterat, dignaretur secum misericorditer in foro conscientie dispensare. [...] Noveritis igitur quod nos, auctoritate nobis commissa, dispensamus cum eodem, super qua dispensatione certos vos reddimus per presentes districte vobis in virtute obedientie, injungentes et, auctoritate ipsius sanctissimi patris et mandato, mandantes, sub pena excommunicationis quam ipso facto incurratis si secus feceritis, quatenus, litteris ipsis perlectis, nulli communicantes easdem, ipsas totaliter lanietis ${ }^{18}$.

${ }^{15}$ M. A. STIEGLER, «Dispensation und Dispensationswesen in ihrer geschichtlichen Entwicklung bis zum 9. Jahrhundert bzw bis Gratian», Archiv für katholisches Kirchenrecht, 77 (1897) 3-75; J. BRYs, De dispensatione in iure canonico praesertim apud decretistas et decretalistas usque ad medium saeculum decimum quartum, De Meester, Wetteren 1925; J. LEDERER, Dispensbegriff des kanonischen Rechts, K. Zink, Munich 1957 (Münchener theologische Studien, Kanonistische Abteilung, III, 8); G. M. CANTARella, «Sondagio sulla "dispensatio" (sec. XI-XII)», in Chiesa, diritto e ordinamento della societas Christiana» nei secoli XI et XII, Atti della nona settimana internazionale di studio (Mendola, 28 agosto-2 sett. 1983), Vita e Pensiero, Milan 1986; A. Lefebvre-Teillard, «Les origines: la dispense en droit canonique», Droits. Revue française de théorie juridique, 25 (1997) 11-18.

${ }^{16}$ C. Eubel (ed.), «Der Registerband des Card.-Grosspönitentiars Bentevenga», Archiv für katholisches Kirchenrecht, 64 (1890) 1-70. The manuscript is kept in Assisi, Biblioteca del Sacro Convento, Fondo antico, mss. 336.

${ }^{17}$ F. Gillmann, «Zur Geschichte des Gebrauchs der Ausdrücke ,irregularis’ und ,Irregularitas'», Archiv für katholisches Kirchenrecht, 91 (1911) 49-86.

${ }^{18}$ Assisi, Biblioteca del Sacro Convento, Fondo antico, ms. 336, ff. 13r-13v. 
This judgment in foro conscientiae does not seem to be related to a secret and sacramental confession, as we have noted that there was no sin nor fault to confess (no peccatum nor culpa). But it is characterized by the destruction of the written proofs and obviously depends on whether the case has caused a «scandal» (scandalum) or not.

I have already shown that in canon law as in judicial and admnistrative documentation, the word scandalum itself never qualifies the sin or the crime. It is more like a semantic landmark; what we could call, in other words, a «meta-pragmatic category» ${ }^{19}$, which overhangs the facts the Roman Church has to face and sets up a backdrop for all the qualifications and the notions describing the circumstances and the consequences of a fault, a sin or a crime ${ }^{20}$. But it also determines the way the case will be settled. In our letter from 1289, we can indeed see that it is because the fault and the irregularity have not provoked any scandal that the Cardinal Penitentiary himself uses the forum conscientiae and allows its recipient to settle the case secretly by destroying the written proof.

In the letter formulary from 1336-1338, composed by the Cardinal Penitentiary Gaucelme de Jean ${ }^{21}$, the same logic is applied to cases of consanguinity. It is once again the lack of scandal which explains that, once received, the letter shall be destroyed by the recipient and that the dispensation shall be granted in foro penitentie.

Priori vel gardiano.

Sua nobis G. lator presentium petitione monstravit quod ipse olim cum Guillelma uxore sua matrimonium contraxit in facie ecclesie, ignorans aliquid esse obstaculum inter eos, et carnali copula subsecuta prolem suscepit ex ea. Cum igitur ad ipsius notitiam nuper pervenerit quod quadam mulier, quam idem G. antea fornicario actu cognoverat, eidem uxori sue in quarta consanguinitatis linea actinebat, et hoc sit occultum, et si divorcium fieret inter eos gravia possent inde scandala exoriri, supplicavit humiliter sibi et dicte uxori sue super hoc per sedem apostolicam misericorditer provideri. Nos autem, cupientes ipsorum conjugum saluti anime provideri, et huiusmodi scandalum obviare, auctoritate etc., tue discretioni committimus quatenus, si est ita, cum dictis conjugibus, quod impedimento hujusmodi non obstante, in suo possint licite matrimonio remanere, in foro penitentie, nullis super hoc adhibitis testibus nullisque concessis litteris sed presentibus laniatis, misericorditer dispenses, prolem exinde susceptam vel suscipiendam legitimam reputando ${ }^{22}$.

We can suppose that no scandal was caused by this illegal marriage - we know that this degree of consanguinity had been prohibited by the Fourth Lateran Council $(1215)^{23}$-, because the Cardinal orders the case to be judged in foro penitentie in order

${ }^{19}$ L. Boltanski, De la critique. Précis de sociologie de l'émancipation, Gallimard, Paris 2009, chap. III, pp. 108-121.

${ }^{20}$ A. Fossier, «Propter vitandum scandalum. Histoire d'une catégorie juridique (XII $-\mathrm{XV}^{\mathrm{e}}$ siècle)», Mélanges de l'École Française de Rome. Moyen Âge, 121/2 (2009) 317-348.

${ }^{21}$ We know seven manuscript copies of this formulary, which has never been edited, but only six have been preserved, since the ms. 594 of the Bibliothèque municipale of Tours has been destroyed by a fire in 1941. Vatican, Biblioteca Apostolica Vaticana, Vat. lat. 5959, ff. 1r-122v; Vatican, Biblioteca Apostolica Vaticana, Ottoboni lat. 333, ff. 1r-88v and ff. 137r-148v; Wien, Österreichische Nationalbibliothek, ms. 415, ff. 38r-120v; Avignon, Bibliothèque Municipale, ms. 336, ff. 1r-55v; Paris, Bibliothèque nationale de France, ms. lat. 4323, ff. 1r-104v; Frankfurt, Stadts- und Universitätsbibliothek, Barth., ms. 80, ff. 89v-222v.

${ }^{22}$ Avignon, Bibliothèque Municipale, ms. 336, f. 38v.

${ }^{23}$ R. Foreville (ed.), Latran I, II, III et Latran IV, Éditions de l'Orante, Paris 1965, p. 371 - 
to avoid the scandal which might be provoked by a divorce (huiusmodi scandalum obviare), but also because the mistake of $« G$.» and his wife is absolutely unknown (cum hoc sit occultum).

Actually, forum penitentie, forum conscientiae and forum confessionis are frequently mentionned when the fact is said to be «occultum». In canon law, the qualification «occultum» was first opposed to «manifestum» by Gratian around 1140, but then it was opposed to «notorium» in the decretals of the 1180 and $1190 \mathrm{~s}^{24}$. Thus, at the end of the $12^{\text {th }}$ century, a distinction was established between, on one hand, «notorious» faults, which cannot be hidden and do not require an investigation since their obviousness renders any testimony useless, and, on the other hand, secret faults, theoretically unfathomable and inaccessible to human and clerical judgment (according to the famous adage of Johannes Teutonicus «Ecclesia de occultis non iudicat») ${ }^{25}$. In reality, the forum penitentie is created at the end of the $12^{\text {th }}$ century by canonists and theologians such as Robert de Courson precisely in order to integrate occult facts into the ecclesiastical system of judgment ${ }^{26}$. In the 1190s, the decretalist Bernardus Papiensis summarizes this position when he writes that clerical judgment can be «manifestum» or «occultum» (as in the case of the penance) $)^{27}$.

In the first regulation of the Penitentiary, which is the Summa de dispensationibus et absolutionibus from $1290^{28}$, two peculiar cases reserved to the Cardinal Penitentiary (casus speciales) must be treated in foro confessionis precisely because the facts are occulta:

-372. About the matrimonial impediments, see A. EsmeIn, Le mariage en droit canonique, Sirey, Paris 1929 [1891]; J. DAuviLlier, Le mariage dans le droit classique de l'Église depuis le Décret de Gratien jusqu'à la mort de Clément V, Sirey, Paris 1933, particularly pp. 205-221; G. Le Bras, «Le mariage dans la théologie et le droit de l'Église du XI" au XIII ${ }^{\mathrm{e}}$ siècle», Cahiers de civilisation médiévale, 11 (1968) 191-202; J. GAUDEMET, Le mariage en Occident : mours et droit, Cerf, Paris 1987; R. WeIgAND, «Die Ausdehnung der Ehehindernisse der Verwandtsachft», Zeitschrift der Savigny-Stiftung für Rechtsgeschichte. Kanonistische Abteilung, 80 (1994) 1-17; F. DEMOULIN, «Exceptio temporis: prescription romaine et dispense en matière matrimoniale au début du XIII ${ }^{\mathrm{e}}$ siècle», in Proceedings of the Tenth International Congress of Medieval Canon Law, Biblioteca Apostolica Vaticana, Città del Vaticano 2001, pp. 943-963 (Monumenta iuris canonici, series C, 11).

${ }^{24}$ C. GHISALBERTI, «La teoria del notorio nel diritto comune», Annali di storia del diritto, 1 (1957) 403-451.

${ }^{25}$ S. KUTTNER, «Ecclesia de occultis non iudicat», in Acta Congressus iuridici internationalis (Rome, 12-17 nov. 1934), vol. 3, Rome 1936, p. 225-246.

${ }^{26}$ V. L. Kennedy, «Robert Courçon on Penance», Medieval Studies, 7 (1945) 291-336; B. FrIES, Forum in der Rechtssprache, op. cit., p. 172; W. TRUSEN, «Zur Bedeutung des geistlichen Forum internum und externum für die spätmittelalterliche Gesellschaft», Zeitchrift der Savigny-Stiftung für Rechtsgeschichte. Kanonistische Abteilung, 107 (1990) 254-285; R. ECKERT, «Peine judiciaire, pénitence et salut entre droit canonique et théologie (XII'-début XIII ${ }^{\mathrm{e}}$ siècle)», Revue d'histoire des religions, 4 (2011) 483-508, pp. 501-503.

${ }^{27}$ Bernard de Pavie, Summa Decretalium, A. T. Laspeyres (ed.), Graz 1956 [1860], p. 56, lib. II, tit. 18, and p. 269, lib. V, tit. 33: «Audivimus de poenis quae inferuntur in iudicio manifesto; nunc de his, quae imponuntur occulto iudicio, audiamus, sive de poenitentiis».

${ }^{28}$ About this Summa, see A. LANG, «Beiträge zur Geschichte der apostolischen Pönitentiarie 
Item potest dominus cardinalis dispensare in foro confessionis sine testibus et litteris super quarto gradu affinitatis cum hoc impedimentum ignorabant contrahentes tempore contracti matrimoni et si erat omnino occultum. [...]

Item potest absolvere falsarios litterarum domini pape qui in ipsis litteris papalibus addidissent unam litteram deficeret errore scriptoris, vel rasissent unam litteram que superhabundaret et ubi per ipsas litteras nullus est processus habitus nec prejudicium aliquod subsecutum. Si tamen falsatio vel rasura modica fuerit et hoc penitus sit occultum absolvere et dispensare cum eis in foro confessionis sine testibus et litteris falsificatis tamen litteris antea lineatis ${ }^{29}$.

Usually in charge of writing a letter of response to the supplications (supplicationes) and to the petitions (petitiones), the Cardinal Penitentiary seems here to judge in foro confessionis when the fact is completely secret (omnino occultum). As we have already seen, the forum confessionis means that the procedure is secret, since all the written proofs shall be destroyed and no witness shall be summoned ${ }^{30}$. But according to this rule, the concern for preserving the secret of a case and avoiding the scandal that the public knowledge of this case might cause also justifies its use.

As it is shown by a letter from Gaucelme de Jean's formulary (1336-1338), forum confessionis refers to the frame in which the secret judgment of a fault, which is itself secret, is pronounced:

Episcopo vel abbati.

Ex parte ... fuit nobis expositum quod olim M. muliere, cum qua publice contraxerat nulla secuta carnali copula, transeunte ad religionem et se in ea professionis vinculo astringeret, idem aliam mulierem quam nunc habet, uxore dicto $M$. in quarto consanguinitatis gradu attinente, tunc huiusmodi consanguinitatis prorsus ignarus, sibi matrimonialiter copulans prolem suscepit ex ea. Quare fecit humiliter supplicari quod, consanguinitate huiusmodi non obstante, in sic contracto matrimonio licite remanere possit, secum dispensare misericorditer curaremus. Nos igitur auctoritate etc., committimus quatenus, si est ita et dictus tempore contracti secundi matrimonii impedimentum huiusmodi ignoravit, et adeo est occultum quod probari non possit aliudque canonicum non obstet, cum eo super premissis in foro confessionis sine testibus et litteris la[ni]atis presentibus misericorditer dispensetis ${ }^{31}$.

Here again, judging in foro confessionis consists in hushing up the matter by destroying the actual and potential proofs (litteris presentibus laniatis and nullis super hoc

im 13. und 14. Jahrhundert», Mitteilungen des Instituts für österreichische Geschichtsforschung, 7 (1904) 36-42; E. GöLLER, Die päpstliche Pönitentiarie von ihrem Ursprung bis zu ihrer Umgestaltung unter Pius V, Loescher, Rome 1907, I, 2, pp. 2-6.

${ }^{29}$ Avignon, BM, ms. 336, ff. 1r-2v.

${ }^{30} \mathrm{~F}$. TAmburinI, «Le dispense matrimoniali come fonte storica nei documenti della Penitenzieria Apostolica (sec. XIII-XVI)», in Le modèle familial européen. Normes, déviances, contrôle du pouvoir, Actes des séminaires organisés par l'École française de Rome et l'Università di Roma (1984), École française de Rome, Rome 1986 (Collection de l’ÉfR, 90), pp. 9-30, here p. 11: «Notiamo che l'impedimento occulto viene dispensato "sine litteris et sine testibus in foro conscientie" o "in foro penitentie" per indicare non tanto un intervento sacramentale quanto piuttosto l'assenza di ogni formalità esterna allo scopo di conservare la segreteza del caso, perciò la supplica che aveva originato la dispensa non veniva registrata o lo era in forma anonima: "tectis nominibus" e non "fictis nominibus", come è stato scritto.»

${ }^{31}$ Avignon, BM, ms. 336, f. 39r. 
adhibitis testibus), but clearly it is the fact that this case of consanguinity is secret that justifies that the dispensation can be granted in foro confessionis.

$* * * *$

We can summarize by saying that the forum confessionis stands for a secret procedure, which is related to the secret nature of a fact, that is to say a fact which has not caused a scandal. However, this forum could also be used before the submission of a case to the Penitentiary, when the supplicant confessed his fault to a priest, a bishop or even an abbot. Let us quote a last letter from the formulary of 1336-1338:

\begin{abstract}
Abbati.
Ex parte tua nobis oblata petitio continebat quod olim frater P. tui monasterii monachus quemdam suum commonachum occulte acriter verberavit [...], et cum esset omnino secretum et etiam offensus offensorem omnino ignoraret, idem frater P. tanquam simplex et juris ignarus, ne hoc in publicum panderetur, $[\ldots]$ recepit ordines et ministravit etiam, $[\ldots]$. In eisdem apertis tamen intelligentie oculis hoc tibi in foro penitentie revelavit. [...] Nos [...] committimus quatenus, si est ita et eius excessus adeo difficilis non fuerit vel enormis, post competentem satisfactionem injuriam passo secrete si adhuc occultum existat exhibitam, ipsum a dicta sententia quam propter hoc incurrit juxta formam ecclesie absolvas, [...] super irregularitate inde contracta super ipsorum ordinum executione dispenses misericorditer cum eodem ${ }^{32}$.
\end{abstract}

The forum penitentie refers without any doubt, even if not explicitly, to the confessio that the monk made to his abbott. We know that, from the $12^{\text {th }}$ century, the confessio becomes a fundamental stage of the penance process, as much as of the civil or penal procedure, and appears more generally to be a major tool of the ecclesiastical discipline of Christian communities at every level of the clerical hierarchy ${ }^{33}$. But I hope to have made clear that the forum confessionis is a very specific sphere of judgment which does not reflect or encompass the entirety of the penitential system of the medieval Church. As it is, the forum of the confession is used in peculiar circumstances, that is when the fact is qualified as occultum, when it has caused no scandal, and when the Church tries to avoid the inevitable scandal that would be caused by the public knowledge of the case.

The forum confessionis or conscientiae is therefore one of the spheres of judgment through which the Apostolic Penitentiary exercises his jurisdiction. It is only a fragment of the large jurisdictional field of the Church, and we can easily discern the difference between the use of confession which consists in keeping the fact hidden, on the one hand, and the many exceptions to the seal of confession that the Inquisition justifies in order to hunt heretics, on the other hand ${ }^{34}$. Nonetheless, the relationship between both uses of confession - keeping it secret or making it public, avoi-

${ }^{32}$ Avignon, BM, ms. 336, f. 21v.

${ }^{33}$ H. Schilling, «Geschichte der Sünde oder Geschichte des Verbrechens. Überlegungen zur Gesellschaftsgeschichte der frühneuzeitlichen Kirchenzucht», Annali dell'Istituto storico italo-germanico in Trento, 12 (1986) 169-192.

${ }^{34}$ ChiffoleaU, «“Ecclesia de occultis non iudicat” ?», particularly pp. 398-401 and 411-418. 
ding scandal or revealing the truth - deserves more attention because the same issue of defence of the Church as institution is at stake. This is precisely what makes the famous topic of utilitas Ecclesiae, which clerical judges had to protect, a very flexible argument... ${ }^{35}$.

${ }^{35}$ E. Cortese, La norma giuridica. Spunti teorici nel diritto comune classico, 2 vol., Giuffrè, Milan 1962-1964, t. 2, pp. 102-109 and 330-335. About the notions of utilitas communis and utilitas publica in canon law, see R. ECKERT, La notion de peine en droit canonique du Décret de Gratien (1140) au concile de Latran IV (1215), mémoire de l'EPHE (supervisor: L. MAYALI), Paris 2007, pp. 80-113; C. LeVeleuX-TeIXeIRA, «L'utilitas publica des canonistes. Un outil de régulation de l'ordre juridique», Revue française d'histoire des idées politiques, 32 (2010) 259-276 , who shows that, by canonists, «public utility» is systemically related to disciplinary issues. It may also regard the internal organization of the Church as an institution, but it can not be considered as a kind of «norme supérieure qui s'imposerait de manière absolue, quels que soient les cas de figure envisagés, mais [doit plutôt l'être] comme un élément d'appréciation relatif, qui doit être jugé par référence à une utilité dite "privée"». 